J. Dairy Sci. 86:3951-3952

(c) American Dairy Science Association, 2003.

\section{Short Communication: Teat Skin pH}

\author{
L. K. Fox, L. Y. Oura, and C. R. Ames \\ College of Veterinary Medicine, \\ Washington State University, \\ Pullman, 99163
}

\begin{abstract}
Changes in teat skin surface $\mathrm{pH}$ were studied over 12 wk in 99 lactating Holstein cows. Half the udder of each cow routinely received postmilking disinfection, and the other half served as control. Measures of $\mathrm{pH}$ were made on all teats at weekly intervals. Teat skin $\mathrm{pH}$ was affected by treatment but not week. Mean teat skin $\mathrm{pH}$ measures were: $7.18( \pm 0.64)$ and $7.53( \pm 0.46)$ for treatment and control teats. In study II, $\mathrm{pH}$ teat skin measures were made hourly on 16 cows, starting $2 \mathrm{~h}$ before milking, immediately before a milking, immediately after a milking, and for $2 \mathrm{~h}$ postmilking. Teat skin $\mathrm{pH}$ was significantly lower for treatment teats and was lower for all teats postmilking.
\end{abstract}

(Key words: teat skin, $\mathrm{pH}$ )

Abbreviation key: GLM = general linear model.

Colonization of the teat by mastitis pathogens is presumed to be a risk factor for IMI (Pankey et al., 1984). The skin's acid mantel is bacteriostatic and retards pathogen growth (Raab, 1990; Chikakane and Taahashi, 1995). Washing of skin will increase the surface $\mathrm{pH}$ (Raab, 1990) and a dairy cow's teats are subjected to several washings per day. Washing may therefore have a negative effect on the maintenance of the acid mantel and might predispose the teat to pathogen colonization. Thus, it would seem important to have an understanding of the factors that influence the dynamics of teat skin $\mathrm{pH}$. The purpose of this study was to determine the changes in teat skin $\mathrm{pH}$ relative to the milking process.

In study 1 the effect of postmilking teat disinfection, dip, on teat skin $\mathrm{pH}$, and changes in teat skin $\mathrm{pH}$ over time as measured weekly, was studied using 99 cows at the Washington State University for a period of 12 wk. This trial was done in conjunction with one reported by Oura et al. (2002). In this trial, the dip used contained $0.32 \%$ sodium chlorite as base, with $2.5 \%$ glyc-

Received June 3, 2003.

Accepted July 25, 2003

Corresponding author: L. K. Fox; e-mail: fox@wsu.edu. erin, $0.27 \%$ sodium dodecylbenzene sulfonic acid, and $1.32 \%$ lactic acid as an included activator. The $\mathrm{pH}$ of the dip was 3.1. A split udder design was used where half the udder received teat dip after milking, while the other half was not dipped and served as a control. Allocation of treatment and control sides (by cow) was by systematic, random assignment. This trial was conducted during the colder months of the year: January through March.

Prior to milking, water from drop hoses were applied to all teats, and visible debris was wiped off with a single-service towel. The surface $\mathrm{pH}$ of the teat skin was measured weekly on each teat of each cow after premilking preparation and before milking unit attachment following the procedure described by Jenkinson and Mabon (1973). In brief, a saturated solution of $\mathrm{NaCl}$ was applied to the center of the surface of the teat closest to the investigator. A glass combination electrode (Corning Flat Surface Combo w/RJ, Corning, NY) using a Corning $\mathrm{pH}-45$ portable meter (Corning) was applied to each teat surface with $\mathrm{NaCl}$ solution. The electrode was held for $20 \mathrm{~s}$ prior to recording the surface $\mathrm{pH}$. The electrode was rinsed with distilled water between measures and it was recalibrated between cows using a commercial $\mathrm{pH}$ standard of 6.0.

During July, a second trial was conducted where 16 cows were randomly selected to determine the changes in teat skin $\mathrm{pH}$ during a 4-h period around a single milking on a single day. Teat skin measures of $\mathrm{pH}$ were made at hourly intervals starting at $2 \mathrm{~h}$ before through $2 \mathrm{~h}$ after milking as described. Two measures were taken at milking time, the first immediately before the milking unit was applied to the mammary gland, and a second immediately after the milking unit was retracted. Thus, 6 measures were made in this segment of the study. Again, only half the mammary gland received postmilking teat asepsis with the product used as described.

In first trial, differences in teat skin $\mathrm{pH}$ were assessed using the general linear model (GLM) analysis where the independent variables considered were: week of measure, cow, and treatment (dipped or control). In the second trial, the GLM model included time of measure relative to milking, cow and treatment, where mean 
Table 1. Changes in teat skin $\mathrm{pH} 2 \mathrm{~h}$ before and $2 \mathrm{~h}$ after milking.

\begin{tabular}{lll}
\hline Period $^{1}$ & Treatment & Control \\
\hline 1 & $7.1^{\mathrm{a}}$ & $7.2^{\mathrm{a}}$ \\
2 & $7.2^{\mathrm{a}}$ & $7.3^{\mathrm{a}}$ \\
3 & $7.3^{\mathrm{a}}$ & $7.2^{\mathrm{a}}$ \\
4 & $6.6^{\mathrm{b}}$ & $6.6^{\mathrm{b}}$ \\
5 & $5.2^{\mathrm{c}}$ & $6.6^{\mathrm{b}}$ \\
6 & $5.5^{\mathrm{c}}$ & $6.8^{\mathrm{b}}$ \\
\hline
\end{tabular}

${ }^{\mathrm{a}, \mathrm{b}}$ Means within a row and column not sharing a common superscript were significantly different.

${ }^{1}$ Measures of $\mathrm{pH}$ were taken hourly, $2 \mathrm{~h}$ before a milking (periods 1 and 2); immediately prior to the milking (period 3), immediately after the milking (Period 4), and hourly $2 \mathrm{~h}$ after the milking (periods 5 and 6$)$.

$\mathrm{pH}$ measures by time were contrasted using Duncan's multiple range test.

The teat skin $\mathrm{pH}$ of cows in the first study was significantly $(P<0.001)$ affected by cow and treatment, but not by week of measure as determined by the GLM. The 12-wk mean $\mathrm{pH}$ of treated teat skin was 7.18 ( \pm $0.64)$ and $7.53( \pm 0.46)$ for control skin. In the second study, differences in teat skin $\mathrm{pH}$ were affected by time period and treatment, means are in Table 1. Teat skin $\mathrm{pH}$ decreased after milking, with a nadir $1 \mathrm{~h}$ after milking, period 5 . The overall mean $\mathrm{pH}$ measures on control teat skin were significantly greater $(P<0.05)$ than treatment group pH measures: $7.0( \pm 0.3)$ vs. $6.5( \pm 0.9)$.

Postmilking teat disinfection can affect teat skin $\mathrm{pH}$. In study 1 , the surface $\mathrm{pH}$ of teat skin became more acidic as teats receiving disinfection had significantly lower $\mathrm{pH}$ values than controls. Presumably, the drop in teat skin $\mathrm{pH}$ with disinfection would have a positive affect on maintenance of the acid mantel and the bacteriostatic properties of the teat skin. It is not known whether the effects on teat skin $\mathrm{pH}$ with the current dip are comparable to other dips, given that there are numerous classes of teat disinfectants available for commercial use (Pankey et al., 1984). Teat skin $\mathrm{pH}$ was not affected by week of trial, suggesting that teat skin $\mathrm{pH}$ is stable over a wide range of time. Although there was no statistically significant week-to-week variation in teat skin $\mathrm{pH}$ as measured in study 1 , daily variation in teat skin $\mathrm{pH}$ was not measured in either study. Thus, the repeatability of $\mathrm{pH}$ measures made in study 2 is unknown. However, the $\mathrm{pH}$ of teat skin in study 1 averaged 7.35 for all cows, very-similar to the $\mathrm{pH}$ of teat skin taken immediately prior to milking, period 3 of study 2 , where $\mathrm{pH}$ averaged 7.25 for all treatments. Thus, both studies together suggest that teat skin $\mathrm{pH}$ for cows managed under similar conditions could be stable.
Results of study 2 indicate that teat skin $\mathrm{pH}$ decreased after milking and that decrease was greatest $1 \mathrm{~h}$ postmilking, and greater in disinfected vs. control teats. Given that the teats are washed prior to milking, and that skin $\mathrm{pH}$ increases after washing (Raab, 1990), it was expected that teat skin $\mathrm{pH}$ would become more basic rather than more acidic after milking. However, the $\mathrm{pH}$ of milk has been reported to be 6.65 (Cecil et al., 1965), and we hypothesize that the milk film on the skin surface after milking was associated with the decrease in surface $\mathrm{pH}$ of the skin of both dipped and control teats. Additionally, the $\mathrm{pH}$ was most acidic on the surface of teat skin that was disinfected. Residual components of the dip likely contributed to the more acidic $\mathrm{pH}$ of treated teat skin. Findings herein suggest that teat skin with an acidic $\mathrm{pH}$ is maintained within $2 \mathrm{~h}$ after milking, and the disinfectant tested was significantly associated with lowered teat skin $\mathrm{pH}$.

Meyer and Neurand (1991) noted that information on the skin surface $\mathrm{pH}$ of mammals other than man was limited. They made a comparative study of skin surface $\mathrm{pH}$ of domesticated and laboratory mammals with a focus to determine a species that might best serve as a model for dermatological research. We are only aware of one study that examined the surface $\mathrm{pH}$ of teat skin of cattle. Jenkinson and Mabon (1973) made extensive measurements of skin $\mathrm{pH}$ of Ayrshire cows including the teat surface. Yet little information was reported regarding the timing of teat skin surface $\mathrm{pH}$ measure relative to milking; neither the premilking udder preparation routine nor the frequency of measures made. The results from our study indicate that the $\mathrm{pH}$ of the teat skin surface can be affected by disinfection, and that such affect may be consistent with maintenance of the acid mantle.

\section{REFERENCES}

Cecil, H. C., J. Bitman, and J. R. Wood. 1965. Changes in milk glycogen during mastitis. J. Dairy Sci. 48:1607-1611.

Chikakane, K., and H. Taahashi. 1995. Measurement of skin $\mathrm{pH}$ and its significance in cutaneous diseases. Clin. Dermatol. 13:299 306.

Meyer, W., and K. Neurand. 1991. Comparison of skin pH in domesticated and laboratory mammals. Arch. Dermatol. Res. 283:16-18.

Jenkinson, D. M., and R. M. Mabon. 1973. The effect of temperature and humidity on skin surface $\mathrm{pH}$ and the ionic composition of skin secretions in Ayrshire cattle. Br. Vet. J. 129:282-295.

Oura, L. Y., L. K. Fox, C. C. Warf, and G. K. Kemp. 2002. Efficacy of two acidified chlorite postmilking teat disinfectants with sodium dodecylbenzene sulfonic acid on prevention of contagious mastitis using an experimental challenge protocol. J. Dairy Sci. 85:252257.

Pankey, J. W., R. J. Eberhart, A. L. Cuming, R. D. Daggett, R. J. Farnsworth, and C. K. McDuff. 1984. Uptake on postmilking teat antisepsis. J. Dairy Sci. 67:1336.

Raab, W. 1990. Skin cleansing in health and disease. Wien. Med. Wochensch. 17(Suppl. 108):4-10. 